The Role of Travel Patterns in Airport Duty-Free Shopping Satisfaction: A case study from an Australian regional airport

\author{
Juan Carlos Martín \\ Institute of Tourism and Sustainable Economic Development \\ Universidad de Las Palmas de Gran Canaria, Spain \\ jcmartin@daea.ulpgc.es \\ Luis Martín-Domingo \\ Faculty of Aviation \\ Ozyegin University, Turkey \\ Luis.Martin@ozyegin.edu.tr
}

\begin{abstract}
Gui Lohmann
Griffith Aviation \& Cities Research Institute

Griffith University, Australia

g.lohmann@griffith.edu.au
\end{abstract}

Bojana Spasojevic

Griffith Aviation \& Griffith Institute for Tourism

Griffith University, Australia

bojana.spasojevic@griffith.edu.au 


\begin{abstract}
Shopping can be one of the primary motivations for tourism, and commercial revenues are becoming an indispensable source of income for airports. Understanding airport shoppers' satisfaction is thus becoming increasingly relevant for airport operators and remains largely unexplored in the academic literature. This paper contributes to the strand of the literature analysing the satisfaction of duty-free shoppers through a six-item construct that was modelled using a hybrid fuzzy TOPSIS (Technique for Order of Preference by Similarity to Ideal Solution) method. A questionnaire was administered at the international terminal of a regional airport in Australia. The results show that the differences in terms of place of residence and passengers' destination route are factors influencing the level of shoppers' satisfaction. Residents in Australia and passengers travelling short-haul are more satisfied than non-residents of Australia and those travelling long-haul. With respect to each attribute, the satisfaction elasticities show that shoppers are more elastic in terms of the variety of items available in the shops and the choice of international brands; and satisfaction is less elastic with respect to the ease with which specific items can be found, as well as the 'look and feel' of the shops.
\end{abstract}

Keywords. Duty-free shoppers' satisfaction; fuzzy logic; TOPSIS; international brands; international routes; Australian airport 


\title{
The Role of Travel Patterns in Airport Duty-Free Shopping Satisfaction: A case study from an Australian regional airport
}

\begin{abstract}
Shopping can be one of the primary motivations for tourism, and commercial revenues are becoming an indispensable source of income for airports. Understanding airport shoppers' satisfaction is thus becoming increasingly relevant for airport operators and remains largely unexplored in the academic literature. This paper contributes to the strand of the literature analysing the satisfaction of duty-free shoppers through a six-item construct that was modelled using a hybrid fuzzy TOPSIS (Technique for Order of Preference by Similarity to Ideal Solution) method. A questionnaire was administered at the international terminal of a regional airport in Australia. The results show that the differences in terms of place of residence and passengers' destination route are factors influencing the level of shoppers' satisfaction. Residents in Australia and passengers travelling short-haul are more satisfied than non-residents of Australia and those travelling long-haul. With respect to each attribute, the satisfaction elasticities show that shoppers are more elastic in terms of the variety of items available in the shops and the choice of international brands; and satisfaction is less elastic with respect to the ease with which specific items can be found, as well as the 'look and feel' of the shops.
\end{abstract}

Keywords. Duty-free shoppers' satisfaction; fuzzy logic; TOPSIS; international brands; international routes; Australian airport

\section{Introduction}

Since the 1990s, a wave of airport privatisation has hit many regions of the world, and private operators are chasing opportunities to increase non-aeronautical revenues (Graham, 2013). Consequently, the importance of commercial management increased at airports (Freathy \& O'Connell, 1999), leading to high percentages of commercial revenues, which reached a world average of 47\% in 2011 (Graham, 2013). Among the various non-aeronautical opportunities are retail (with an average global contribution of $28 \%$ in terms of the multiple sources of nonaeronautical revenues), followed by parking at 22\% (ACI, 2015).

Within retail, duty-free is the most important source of income for international airports. For instance, at London Heathrow, duty-free revenues represent near one-third of the total retail revenue (Gleave, 2017). The contribution of duty-free revenues at international airports has encouraged airport operators, and their retail partners, to increase their interest in understanding the purchasing behaviour of travellers. In particular, airport managers are interested in knowing the factors that contribute to increasing duty-free shopping satisfaction and revenues.

To date, research on satisfaction in the context of airport duty-free shopping has not received much attention and has been limited to two airports in Asia: Seoul Incheon (Perng, Chow, \& Liao, 2010; Lin \& Chen, 2013) and Taiwan Taoyuan (Lin \& Chen, 2013). Different cultures have different service requirements and expectations (Lin \& Chen, 2013), which need to be well understood by airport managers to provide excellent service. 
This empirical research measures airport duty-free shoppers' satisfaction and the elasticity of satisfaction concerning six attributes at one international regional airport. The chosen geographical location is Australia, where airport privatisation took place in the 1990s, with many airports having achieved high levels of commercialisation and non-aeronautical revenue generation. This research contributes to the literature providing further insights from Australia through the use of a different methodology (the hybrid fuzzy TOPSIS).

The aim of this empirical paper is threefold: (1) to understand the satisfaction of airport duty-free shoppers in a commercially driven environment; (2) to analyse the influence of travel patterns in shopping satisfaction; and (3) to find critical success attributes to enhance the satisfaction of airport duty-free shoppers.

2. Shopping behaviour and duty-free shop

In terms of the definition for duty-free shops, the Airport Cooperative Research Program (2011, p. 14) considers them as: "retail shops that mainly sell high-end luxury goods in five traditional core categories: perfumes and cosmetics, liquor, tobacco, fashion, and chocolates/confectionery. Duty-free shops, with some exceptions, sell merchandise that is free of import duties, excise taxes, and local and state sales taxes." Airport shopping behaviour has been studied by transferring the main theories that are applied in other shopping contexts where the roles of attitudes, emotions, willingness, motivations and conations have been more deeply analysed (Han et al., $2014 \mathrm{a}, \mathrm{b}$, 2015). Shopping at airports, particularly at duty-free shops, is an integral and sought-after experience for travellers, creating a significant source of income for international airports (Hobson, 2000). Thus, understanding passengers' shopping behaviour is critical for airport managers since satisfaction plays a vital role in the overall behaviour of customers (Park, Choi \& Moon, 2013) by affecting, particularly, their purchasing decisions (Han, Hwang \& Kim, 2015).

Geuens, Vantomme, and Brengman (2004) identified that while up to $40 \%$ of travellers would not shop at airports, there are still approximately six out of ten travellers who do. Omar and Kent (2001), as well as Sohn and Lee (2016), found that shoppers travelling through international airport duty-free outlets frequently made purchases based on impulse and emotion rather than any specific need. Omar and Kent (2001), in particular, found evidence that "impulse shopping at the airports is induced and/or encouraged by both marketing and environmental influences” (p. 233). The list of the attributes that are analysed in their study belongs to two of the leading marketing components - the product (i.e., variety, international brands and gift ideas) and the environment (i.e., ease of finding, staff and look \& feel of the shops).

Airport planners use a number of features to influence and facilitate shopping, including interior design components such as the lighting, artwork, and terminal layout (Hubregtse, 2016). The influence of the design on passengers' shopping behaviour is supported by the work of Graham (2009), who suggests that airport terminals and retail outlets must create appealing and relaxing environments that positively influence passengers to engage with retail outlets. Other factors, such as culture, traffic volume, available shopping time and stress levels, influence passengers' behaviour at airports (Perng, Chow \& Laio 2010). Lin \& Chen (2013) observe that the nationality of passengers is a moderating factor of airport passengers' satisfaction.

Since walking through certain areas of an airport, including security and check-in, can be less than relaxing for passengers, duty-free shops are strategically located after the "airport stressful areas" 
so that passengers can relax and enjoy the shopping time (Crawford and Melewar, 2003; Hubregtse, 2016). By reducing the time passengers stay at stressful situations (e.g. immigration checkpoints) and increasing their time in the areas of the airport that are designed for relaxation, airports managers can ensure that passengers will be more likely to make retail purchases (Geuens et al., 2004; Hubregtse, 2016; Crawford and Melewar, 2003; Torres et al., 2005). These shopping opportunities will also be enhanced by understanding passengers shopping motivations and preferences.

Two separate studies that were conducted at Taiwan Taoyuan International Airport provide a detailed analysis of the factors and variables that influence passengers' shopping experiences. Perng, Chow, and Liao (2010) defined seven commercial airport product categories: utility, entertainment, brand name, low cost, service, souvenir and F\&B (food and beverage). Using grey relation analysis (GRA), these authors found that brand-name products (generally luxury products) generate the highest satisfaction for passengers, followed by utility products (i.e., functional and applicable) and low-cost products (i.e., products that provide value for the money). Additionally, Lin \& Chen (2013) considered shopping satisfaction at duty-free stores at the Taiwanese airport based on three dimensions: product, service, and shopping environment. By applying ridit analysis, they identified the cultural differences between Japanese, Taiwanese and foreign passengers, and how the type of product and the price impact passengers' satisfaction.

Additionally, in the context of Asian airports, duty-free research that was carried out at Seoul Incheon International Airport analysed the effects of sales promotions on the behavioural intentions of customers. Park et al. (2013) applied a structural equation model to twenty variables, which were grouped into five measures: sales promotion, customer satisfaction, corporate image, customer value, and behavioural intentions. They concluded that price and promotion have a definite impact on passenger satisfaction and intentions.

A fewer number of studies conducted in other parts of the world highlight significant differences among passenger profiles. In a survey carried out at Brussels Airport, Geuens et al. (2004) defined two airport shopping motivations: traditional shopping motivations (experiential and functional) and airport-related motivations (infrastructure and atmosphere). Experiential motivations and shopping atmosphere had the most significant influences on airport shoppers who were divided into three typologies: mood shoppers, shopping lovers, and apathetic shoppers. From a typological point of view, Geuens et al. (2004) were able to prove a distinction between male and female shopping motivations. While men tended to be more apathetic shoppers, women tended to be shopping lovers. Additionally, Omar and Kent (2001) found that those travelling alone usually have fewer inhibitions to make impulse purchases. Depending on the purpose of travel, leisure passengers are more likely to make a purchase (Kleinschmidt et al., 2011) that is influenced by convenience and the cultural obligation to purchase gifts for friends and relatives. Torres et al. (2005) also found that business passengers tend to spend less than leisure passengers.

In Australia and New Zealand, the light-handed airport regulation has strongly influenced the development of non-aeronautical retail businesses. The light-handed regulation means that there is no specific price regulation, but it could be imposed in case airports underperform (Forsyth, 2006). In this circumstance, the level of non-aeronautical income generation became dependant on the airport management model rather than the ownership structure (Moulds \& Lohmann, 2016). In their study on Adelaide Airport in South Australia, Moulds and Lohmann (2016) identified the potential change in duty-free shopping patterns as one of the key challenges for non-aeronautical 
revenues. Thus, the authors reinforce the need to analyse the duty-free passengers' shopping satisfaction in Australia, since the only existing evidence comes from Korea and Taiwan.

\section{Methods}

\section{The Case Study Airport:}

An Australian airport was used as a case study, considering the level of commercialisation that airports in the country have reached after 25 years of a successful privatisation process (Hooper, Cain \& White, 2000). In the context of the Australian 'light-handed' regulatory system (Kistler et al., 2018), non-aeronautical revenues are significantly rising. The chosen airport generated, on average, $47.8 \%$ of its revenues from non-aeronautical sources during the last ten years, and it reached its peak of $50.6 \%$ in 2015 . Although there are significant differences among the various types of airports and regions around the world, the non-aeronautical revenue share of the analysed Australian airport in 2014 (50.3\%) was slightly higher than the global average (44.5\%) (ACI, 2015).

\section{Instrument Design}

Surveys are widely used by industry and academics to collect passenger information at terminals. Some examples include the ASQ (Airport Service Quality) that was conducted by Airport Council International across hundreds of airports around the world, as well as other large national tourist surveys, such as the International Visitor Survey (IVS) in Australia. Several academic studies have also conducted surveys to understand passengers' shopping behaviours at airports (Chung, Wu \& Chiang, 2013; Lin \& Chen, 2013), particularly due to the following benefits: (1) it is an effective way of enlisting cooperation; (2) the interviewer administering the survey can probe for adequate answers; (3) longer survey instruments are more possible in person than when using any other method; (4) it is a guaranteed way to obtain a certain sample size; and (5) passengers can immediately evaluate their shopping experience at the airport when compared to online or mail surveys (Fowler Jr, 2013).

The instrument that was designed for this survey comprised three main parts. The first section collected information about the passengers' travel patterns, including their country of origin (the postcode was collected if living in Australia), the flight number (which gives information about the international destination, the time of the flight and the airline), the use of an airline lounge, the purpose of the trip, the size of the party, and the number of nights away as part of the trip.

The second section inquired about the shopping behaviour of passengers, including questions regarding how far in advance passengers arrived at the airport, the main reason for purchasing (or not) at the airport, the quality of service of the duty-free shops, how much was spent on duty-free goods, and the methods of payment that were used. This section dealt with the satisfaction of shoppers and it is adapted from Lin and Chen (2013). Thus, the questions contained six items where the answer format was based on a 5-point semantic Likert scale (very poor, poor, neutral, good and very good). In this study, the six attributes that were used to ascertain the duty-free shoppers' satisfaction were the following: (1) the variety of products and items that were available, (2) the choice of international brands, (3) the ease of finding specific items, (4) gift ideas and choices, (5) helpful and friendly staff, and (6) the look and feel of the shops. The look and feel of the duty-free shops resemble Section 4 of the questionnaire that was developed by Lin and Chen (2013), which was named "environment". The authors included seven items as part of this factor: (i) lighting, (ii) interior decoration and design, (iii) product display, (iv) flow of the shopping, (v) 
spatial comfort, (vi) cleanness and hygiene, and (vii) service counter. After analysing the answers to the open-ended questions, the authors concluded that the complaints were of little relevance, and they referred to poorly organised product displays and unclear labelling. From Lin and Chen's analysis, it can be inferred that the complaints were related to the "ease of finding specific items", which is one of the attributes included in our questionnaire.

The third section of the survey focused on the profile of the passenger, with questions related to their socio-demographic characteristics (e.g., age, gender, and frequency of overseas trips) and the use of social media.

The survey (see Appendix 1) was uploaded in the iSurvey app, which was installed on several iPad devices. The Australia-based authors, as well as trained research assistants, then read the questions and answers (in the case of the closed questions), and the answers were recorded on the device.

\section{Sampling}

The passengers were approached inside the international terminal while waiting to board their flights. Previous research experience from the authors has demonstrated that targeting outbound passengers at the gates was the best approach in terms of success rate. Before going through the immigration area, passengers tend to be predominantly concerned with their check-in, immigration and eventually duty-free shopping. When they reach the boarding gates, passengers are then able to relax. Additionally, approaching passengers after they have been through the duty-free area is the only option to capture their shopping experience.

Only people over the age of 18 years were targeted (as per ethics requirement), and only one person in a group was approached. During the data collection period, the airport served eight international destinations in Asia, the Middle East and New Zealand. To obtain a sample that was large enough to be representative of the overall airport passenger population, particularly regarding segmenting this sample into the specific sub-samples of destinations, a total of 850 surveys were conducted. The eighth international destinations (Auckland, Denpasar, Doha, Guangzhou, Hong Kong, Kuala Lumpur, Nadi and Singapore) were proportionally represented according to the number of passenger flown in August 2017. A total of 761 valid responses were obtained. Regarding the sampling error, the worst scenario (11.7\%), assuming a 95 per cent confidence level and $\mathrm{p}=\mathrm{q}=0.5$, was obtained for Doha (69 valid responses). In any case, the actual representation of duty-free costumers based on flight destination is unknown to the researchers and the airport managers. Hence, it is challenging to make any association between the overall population of international passengers and duty-free costumers based on their flight destinations.

\section{Respondents' profiles}

Concerning the profiles of the respondents, some of the key information that is relevant to this study includes gender, age, place of residence, frequency of overseas trips and the purpose of the trip. In terms of gender distribution, there were slightly more female respondents (54.8\%). Males represented $44.9 \%$ of the sample. There was a small number of passengers who preferred not to declare their gender $(0.3 \%)$.

The age bracket intervals that were used by the Australian Bureau of Statistics (ABS) were followed to facilitate the comparison of the passenger profile with the overall population living in the airport's catchment area and the IVS (International Visitor Survey) data. When compared with the total population of the Greater city area, it is possible to identify a higher representation of passengers across the 25 -34 age bracket (23.4\%) than that of the general population (16.7\%). The 
percentage of passengers in the 35-44 age bracket (16.8\%) is very similar to that in the Greater city population (17.26\%). The number of passengers over the age of 45 is slightly less in comparison with the overall Greater city population. These results strongly suggest that the air transport passengers from the airport catchment area are somewhat dominated by younger adults and adults, with the $18-44$ years old brackets comprising $53.6 \%$ of the overall passenger sample $(n=761)$, followed by $40.2 \%$ of the passengers being from the $45-69$ years old brackets.

Regarding the place of residence, $82.8 \%$ of passengers that were interviewed live in Australia. Of those passengers, 97.9\% identified their place of residence with a state-level postcode. The remaining 2\% live in other States of Australia. Non-Australian residents represented less than 20\% of the total sample, with a diverse number of countries of residence being represented. The sample included overseas passengers from New Zealand, which is the leading market of international visitors (27.5\%), followed by China (mainland) (19.1\%), Hong Kong (18.3\%), Malaysia (9.2\%) and the UK (6.9\%). Apart from New Zealand, Asian visitors represented a dominant portion (41.3\% of the overall sample). European countries (excluding the UK) represent only $6.9 \%$ of the sample.

The majority of passengers travels overseas at least once a year (62\%). Meanwhile, $24.3 \%$ of the passengers travel every two years and $10.6 \%$ travel every five years. For 3.3\% of the passengers, this was their first overseas trip. The vast majority of respondents identified a "holiday" as the main purpose of their trip (68.5\%), followed by VFR ("visiting friends and relatives") (17.3\%) and business, conferences and events (10.6\%). All other reasons for travel, including education and transit through the airport, represented only 3.6\% of the overall sample. Approximately 95 per cent of the passengers did not use any airline lounges. Regarding the size of the group that was travelling together, it is observed that 31 per cent of the passengers travelled alone, 44 per cent travelled with his/her partner or one companion, and the rest of the passengers travel in groups of three or more people.

\section{Analytical Tools}

As explained, the dataset that was obtained from the survey is based on the responses to a 5-point semantic Likert scale. Carifio and Perla (2008) discuss how Likert scales should be appropriately used by researchers regarding the two main competing views that exist regarding the types of scales: ordinal vs interval. The authors contend that the debate concerning Likert scales strongly favours the intervalist position, and, therefore, it is appropriate to sum Likert items and analyse the sums parametrically using both univariate and multivariate econometrics. Nevertheless, beyond the strategies of intervalists or ordinalists, other methodological positions can be applied, such as that of fuzzy logic practitioners who advocate the use of the interval concept, which employs fuzzy numbers as a way to resolve the inherent uncertainty that is associated with Likert scales assessments (Hu, 2009).

A hybrid fuzzy multi-criteria decision-making method, which is based on fuzzy logic and the technique for the order of preference by similarity to ideal solution (TOPSIS), is proposed in this study. This method aims to calculate a synthetic satisfaction indicator for duty-free airport shoppers. This method is gaining popularity for measuring service quality or satisfaction in different tourism and transport related research areas, including hotels (Benitez et al., 2007; Martín \& Román, 2017), public transport (Celik et al., 2016; Dehghani et al., 2017), railroads (Aydin, 2017; Tang et al., 2017), airports (Kazemi et al., 2016; Tlig \& Rebai, 2017), events (Martín et al., 2017a,b), and logistics (Gupta et al., 2012; Yazdani et al., 2017). 
The proposed hybrid method is based on the fundamentals of fuzzy logic (Zadeh, 1965; 1973). The hybrid fuzzy methods have been developed to handle the uncertainty that is associated with the information that is provided by respondents to questions that are based on semantic or linguistic Likert scales. It is well known that these scales are often used in social science and business management surveys because they are well suited to the way that human beings think or make judgements.

Figure 1 shows the main steps of the method used in this study. (1) The information matrix (attributes-respondents), which is provided by the individual shoppers for all the attributes that are included in the analysis, is converted into a matrix (attributes and segments) of triangular fuzzy numbers. The matrix is converted using a function that depends on the fundamental properties of the algebra of fuzzy numbers. The representation of the semantic Likert scale items using triangular fuzzy numbers (TFNs) is selected in this phase. (2) The raw information TFN matrix is clarified. (3) The positive and negative ideal solutions are obtained. (4) The synthetic satisfaction indicators are obtained for each segment. (5) The elasticity of the satisfaction is achieved for each segment with respect to all the attributes.

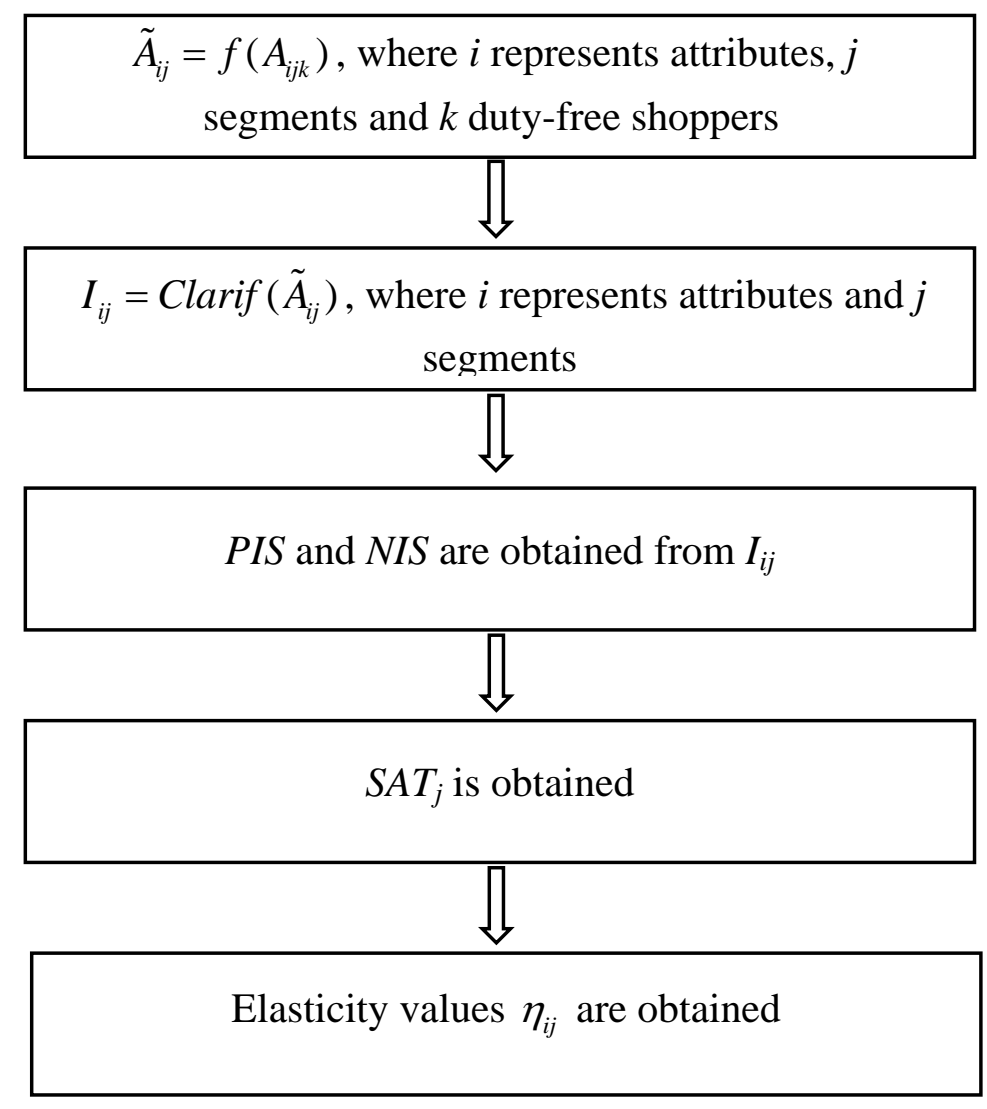

Figure 1 The steps of the hybrid method

Table 1 shows how each linguistic term in the Likert scale is represented by a TFN. The definition of the TFNs, the membership function and the fuzzy algebraic operations can be found in other papers (Hu, 2009; Martín \& Román, 2017). TFNs are probably the most employed fuzzy sets that 
provide the basis for the analysis of complex systems in which linguistic rather than numerical variables describe the performance of the object of study. TFNs are represented by a triplet of ordered real numbers that determine the universe or discourse of the fuzzy set. In essence, TFNs are characterised by giving the maximum (1) and minimum (0) likelihood of membership to the centre and the extremes of the triplet. The TFN membership function can be expressed mathematically as follows:

$$
\mu_{A}(x)=\left\{\begin{array}{l}
\frac{x-a_{1}}{a_{2}-a_{1}}, \quad a_{1} \leq x \leq a_{2}, \\
\frac{x-a_{3}}{a_{2}-a_{3}}, \quad a_{2} \leq x \leq a_{3}, \\
0, \quad \text { otherwise }
\end{array}\right.
$$

It is said that the TFN is degenerated when two elements of the triplet coincide. It can be noticed that the extreme points are degenerated at the beginning and end of the interval 0-100 and that the length of the range is 30 when the satisfaction is verbally expressed as very poor or very good. Thus, the researchers assumed that the uncertainty that is associated with each extreme of the scale is the same. In other studies, this assumption could be changed depending on the characteristics of the concept that is under investigation. The range of the rest of the intermediate TFNs is equal to 20 , a value that is ten units lower than the extreme cases, and the intervals are symmetrically centred on the most likely values of 30,50 and 70, respectively. In all instances, it can be seen that the information that is provided by the linguistic terms is not precise since all of the consecutive linguistic terms have an area of intersection that is not empty. In the case of very poor and poor, this overlapped area is determined by the interval $(20,30)$, and this shows the nature of the fuzzy set theory in which an element can reside in more than one set.

Table 1 Triangular Fuzzy Numbers TFNs. Representatives of the Likert scale

\begin{tabular}{cc}
\hline Linguistic term & TFNs \\
\hline Very poor & $(0,0,30)$ \\
Poor & $(20,30,40)$ \\
Neutral & $(30,50,70)$ \\
Good & $(60,70,80)$ \\
Very good & $(70,100,100)$ \\
\hline
\end{tabular}

The individual information matrix is converted to the segment matrix using two basic operations of the algebra of the TFNs (Buckley, 1985), and $\tilde{A}_{i j}$ is obtained as the average value of $n$ TFNs as follows: 


$$
\bar{A}_{i j}=\left(\bar{a}_{i j 1}, \bar{a}_{i j 2}, \bar{a}_{i j 3}\right)=\left(\frac{1}{n}\right) \bullet\left(\tilde{A}_{i 1} \oplus \tilde{A}_{i 2} \oplus \cdots \tilde{A}_{i n}\right)=\left(\frac{\sum_{k=1}^{n} \tilde{a}_{i k 1}, \sum_{k=1}^{n} \tilde{a}_{i k 2}, \sum_{k=1}^{n} \tilde{a}_{i k 3}}{n}\right)
$$

where $\bar{A}_{i j}$ and $\tilde{A}_{i k}(k=1 \ldots n)$ are TFNs, • is the external operator of a scalar and a fuzzy number, and $\oplus$ is the sum operator of the fuzzy numbers. The algebra of fuzzy numbers guarantees that $\bar{A}_{i j}$, which is the average value that is calculated for each segment that can be considered of interest in the research (e.g., flight destination), is also a TFN. Thus, this step is characterised by the average values of all the respondents that belong to each of the segments that are considered in the study. The survey that was conducted at the airport permitted the analysis of 178 different segments that depended on several socio-demographic and other segmentation variables.

The clarification phase depends on what is known as the expected value (EV) of a fuzzy number or the best-non-fuzzy performance of the fuzzy number. There are some different techniques to clarify the information that is provided by the fuzzy numbers, but, analogously to other studies, the EV is here defined as follows: $v_{\tilde{A}}=\left(\bar{a}_{i j 1}+2 \bar{a}_{i j 2}+\bar{a}_{i j 3}\right) / 4$. This method has been used by other researchers after Chen (1996), and it is a simple but very useful way to extract the crisp (binary values) information of a fuzzy number. The method also presents some other additional advantages over other more sophisticated techniques such as, for example, the lack of any prior requirement that researchers need to impose about the pessimism or optimism regarding the possible results (Martín \& Román, 2017).

The third step obtains the ideal solutions following the logic that the positive ideal solution is the one that maximises all the criteria that are associated with benefits and minimises all the criteria that are related to costs. Thus, for each attribute $i$ and all the observed airport duty-free shopper segments $j$, the positive ideal solution vector is obtained with the best observed satisfaction in the sample. Similarly, the ideal negative solution is obtained since the observation is characterised by minimising all the criteria that are associated with benefits and maximising all the requirements that are related to costs. Thus, the ideal solutions are computed as follows:

$$
\begin{aligned}
& P I S=\left\{\left(\max V_{i j} \mid j \in J\right), i=1,2, \ldots, 6\right\} \\
& N I S=\left\{\left(\min V_{i j} \mid j \in J\right), i=1,2, \ldots, 6\right\}
\end{aligned}
$$

The fourth phase determines the relative distance of each observation by each segment using the vectors that are obtained in Equations 3 and 4. This is done by applying the TOPSIS method (Hwang \& Yoon, 1981; Zeleny, 1982). Similar to other ranking problems, it can be determined that segment $i$ would be more satisfied than segment $j$ when the synthetic indicator of the $i$-th observation is greater than the synthetic indicator of the $j$-th observation. The ranking of all the segments according to the experienced satisfaction is now possible by comparing the synthetic satisfaction indicator that is obtained by TOPSIS.

Mathematically, the synthetic satisfaction index SAT for each segment $j$ is determined as follows: 


$$
\begin{gathered}
S_{j}^{+}=\operatorname{dist}\left(V_{j}, P I S\right)=\sqrt{\sum_{i=1}^{6}\left(V_{i j}-P I S_{i}\right)^{2}} \quad j \in J \\
S_{j}^{-}=\operatorname{dist}\left(V_{j}, N I S\right)=\sqrt{\sum_{i=1}^{6}\left(V_{i j}-N I S_{i}\right)^{2}} \quad j \in J \\
S A T_{j}=\frac{S_{j}^{-}}{S_{j}^{+}+S_{j}^{-}} \quad j \in J
\end{gathered}
$$

The above equations show that the synthetic indicator depends on the distance of each observed segment concerning the ideal solutions, and how far each observation is from the negative ideal solution. Equation 6 can be used to obtain the satisfaction that each segment experiences. This approach has been used to measure the overall passenger satisfaction at airports and the customers' satisfaction at F\&B retailers (Chiappa et al., 2016; Kazemi et al., 2016; Tlig \& Rebai, 2017).

Finally, the fifth phase is used to calculate the elasticities of the SAT index concerning all the attributes for each segment as a way to obtain the critical success factors that can be used to design better services. The elasticity measures how the SAT varies with respect to marginal changes for each of the attributes that are considered in the analysis. The elasticity is usually understood or defined as the percentage change variation. In mathematical notation, the elasticity can be calculated for each segment $j$ and each satisfaction attribute $i$ as follows:

$$
\eta_{i j}=\frac{\Delta \% S A T_{j}}{\Delta \% V_{i j}}=\frac{d S A T_{j}}{d V_{i j}} \frac{V_{i j}}{S A T_{j}}
$$

Airport managers that are responsible for duty-free facilities can consider the elasticity for each of the segments to better adjust the service provision, thereby increasing the level of satisfaction for each segment.

\section{Results}

Table 2 presents the results of the first two phases of the proposed hybrid fuzzy method. The Expected values (EVs) under the "crisp” column aim to facilitate the reading of Table 2 for readers who are not familiar with triangular fuzzy numbers (TFNs). It can be noticed that Australians are more satisfied than foreigners with respect to all the attributes with the clarified values being higher for Australians than for foreigners. In more detail, it is also observed that the gap is the largest for the choice of international brands and the lowest for the satisfaction that is experienced regarding the helpfulness and friendliness of the staff. In many respects, this can be expected considering that international visitors are more likely to have been exposed to many more duty-free shops on their travels, particularly those in Europe, the Middle East and Asia that have consistently been ranked among the best in the world. 
Table 2 TFNs and Crisp information for three segments: Total, Australian and non-Australian residents.

\begin{tabular}{|c|c|c|c|c|c|c|}
\hline \multirow{2}{*}{ Attribute } & \multicolumn{2}{|l|}{ Total } & \multicolumn{2}{|c|}{ Australian resident } & \multicolumn{2}{|c|}{ Non-Australian resident } \\
\hline & TFN & Crisp & TFN & Crisp & TFN & Crisp \\
\hline $\begin{array}{l}\text { Variety of product } \\
\text { items available }\end{array}$ & $(50.8,65.9,76.9)$ & 64.9 & $(51.7,66.9,77.7)$ & 65.8 & $(46.4,61.4,72.9)$ & 60.5 \\
\hline $\begin{array}{l}\text { Choice of } \\
\text { international } \\
\text { brands }\end{array}$ & $(48.8,64.6,76.3)$ & 63.6 & $(50.3,66.2,77.6)$ & 65.1 & $(41.9,57.4,70.4)$ & 56.8 \\
\hline $\begin{array}{l}\text { Ease of finding a } \\
\text { specific item you } \\
\text { were looking for }\end{array}$ & $(57.8,75.0,83.3)$ & 72.8 & $(58.1,75.6,83.7)$ & 73.3 & $(56.6,72.2,81.2)$ & 70.6 \\
\hline $\begin{array}{l}\text { Gifting ideas and } \\
\text { choices }\end{array}$ & $(53.2,68.1,78.8)$ & 67.1 & $(53.6,68.5,79.2)$ & 67.5 & $(51.6,66.6,77.4)$ & 65.5 \\
\hline $\begin{array}{l}\text { Helpful and } \\
\text { friendly staff }\end{array}$ & $(62.5,82.3,88.4)$ & 78.9 & $(62.6,82.7,88.6)$ & 79.2 & $(61.9,80.6,87.3)$ & 77.6 \\
\hline $\begin{array}{l}\text { The look and feel } \\
\text { of the shops }\end{array}$ & $(56.5,73.2,82.2)$ & 71.3 & $(56.9,73.7,82.6)$ & 71.7 & $(54.7,70.6,80.4)$ & 69.1 \\
\hline
\end{tabular}

Table 3 shows the positive and negative ideal solutions and percentage variation for the six attributes that are included in the analysis. It provides insights for airport managers to know which attributes generate more or less satisfaction for particular segments, and which attributes are more or less homogeneous. According to the results that are obtained, it can be concluded that none of the representative segments is characterised by the segmentation variables that are used in our analysis, and so it is less than straightforward to determine any possible results regarding the satisfaction of the particular segments under analysis.

Table 3 Ideal Solutions

\begin{tabular}{|c|c|c|c|c|c|}
\hline Attribute & $\begin{array}{l}\text { PIS }(\mathrm{Pc} \\
\text { Value }\end{array}$ & $\begin{array}{l}\text { sitive Ideal Solution) } \\
\text { Segment }\end{array}$ & $\begin{array}{l}\text { NIS }(\mathrm{Ne} \\
\text { Value }\end{array}$ & $\begin{array}{l}\text { egative Ideal Solution) } \\
\text { Segment }\end{array}$ & $\begin{array}{c}\% \\
\text { Variation }\end{array}$ \\
\hline Variety of product items available & 85.0 & 'Trip.Purpose.Other' & 30.0 & '2 Nights' & 183.3 \\
\hline Choice of international brands & 83.9 & 'Airport.App.Maps(5)' & 30.0 & 'Trip.Purpose.Transit' & 179.5 \\
\hline $\begin{array}{l}\text { Ease of finding a specific item you } \\
\text { were looking for }\end{array}$ & 86.4 & 'Expenditure. 50-99' & 49.2 & 'Age. 75-79' & 75.7 \\
\hline Gifting ideas and choices & 81.3 & 'Airport.App.Maps(5)' & 35.8 & '2' Nights & 126.7 \\
\hline Helpful and friendly staff & 92.5 & 'Airport.App(NA)' & 50.0 & $\begin{array}{l}\text { 'Airport.App. } \\
\text { Flighttimes(1)' }\end{array}$ & 85.0 \\
\hline The look and feel of the shops & 81.3 & '2 Nights' & 30.0 & $\begin{array}{l}\text { 'Airport.App. } \\
\text { Flighttimes(2)' }\end{array}$ & 170.8 \\
\hline
\end{tabular}


Nevertheless, it can be observed that travellers on a short stay (two nights) score well on 'the look and feel' of the airport, but would like to see more variety of products and be able to more easily find the products in which they are interested. Passengers who would like to see more visual information about the layout of the airport (e.g. maps on an app) score well on the existing choice of international brands and gift ideas, and passengers who appreciated having real-time information about flights (Airport App Flightiness) are not happy with the duty-free staff or the look and feel of the shops.

Regarding the values, it is observed that for the majority of the attributes, the NIS vector is characterised by figures lower than 50, except for helpful and friendly staff. It can also be seen that there is more heterogeneity in the attributes of the variety of products and items that are available and select international brands, which is in contrast with the more homogenous characteristics such as the ease with which specific items can be found and helpful and friendly staff. The values of the PIS are in all cases higher than 80, and a particular segment (Airport App Not Available) rates the helpfulness and friendliness of the staff at the maximum level (i.e. very satisfied).

Regarding the results of the satisfaction index, the fourth phase, it can be seen from Figures 2 and 3 that the place of residence and the destination have moderating effects on airport duty-free shoppers' satisfaction. Figure 2 shows that Australian residents are more satisfied than nonAustralian residents, and Figure 3 points out that shoppers flying to AKL (Auckland, New Zealand) are the most satisfied while shoppers flying to CAN (Guangzhou, China) are the least satisfied. It becomes apparent that the preferences or constraints of these two segments are very different, and further in-depth analysis needs to be made by airport managers. Another interesting factor to highlight here is that the flying destination can also be affected by different percentages of Australian residents and Non-Australian residents flying on those flights.

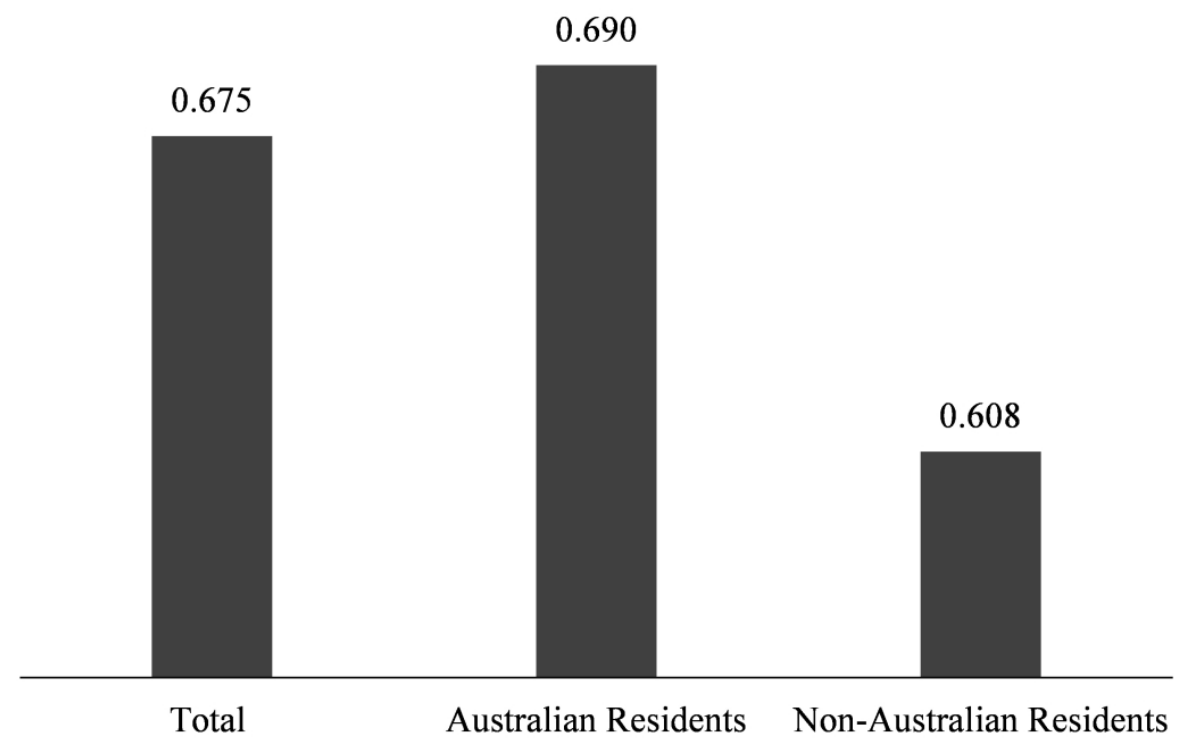

Figure 2 Airport duty-free shoppers' satisfaction index by place of residence 


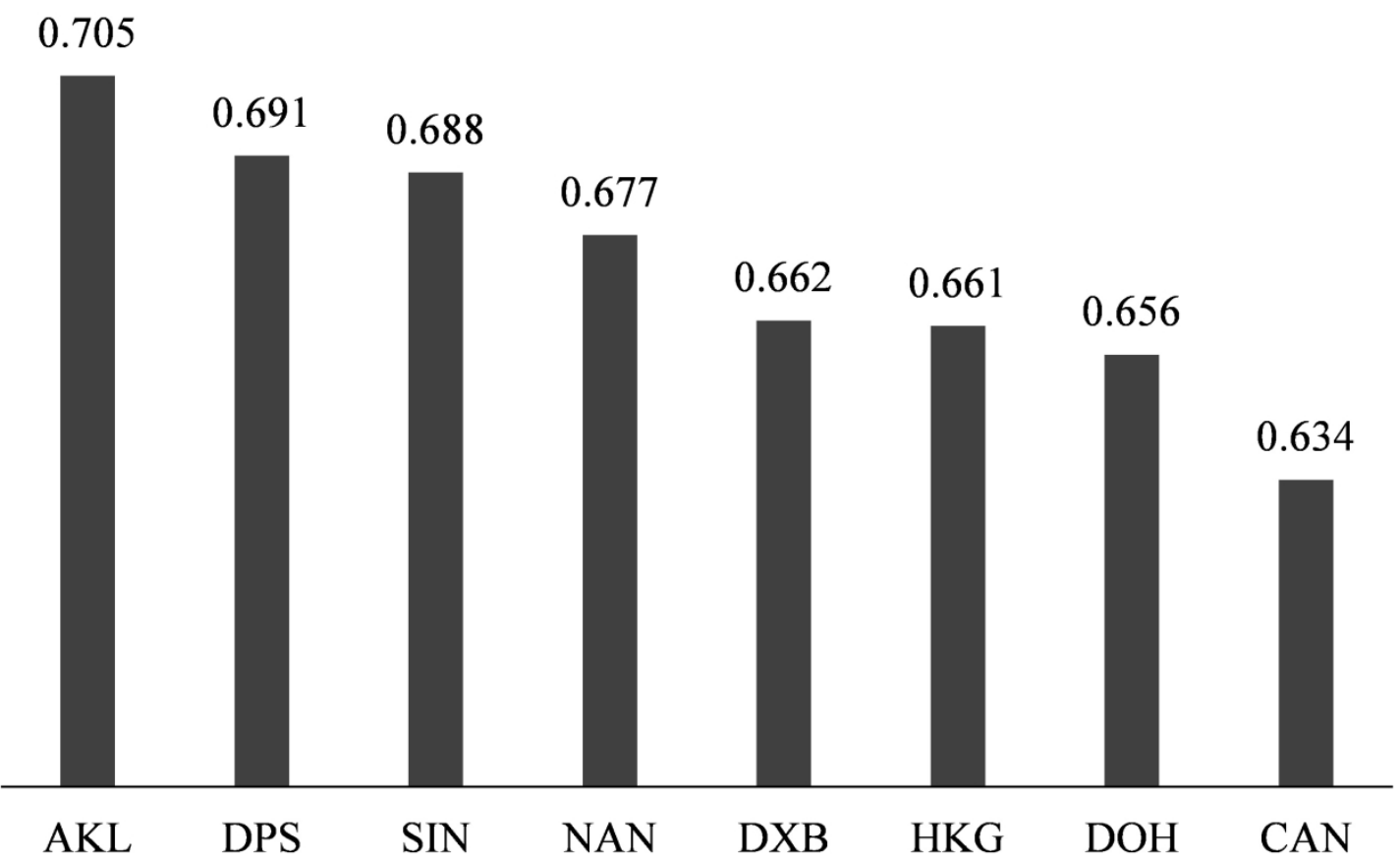

Figure 3 Airport duty-free shoppers' satisfaction index by destination

As explained above, the elasticities show the SAT changes in percentages for the destinations that are included in the analysis with respect to one per cent variation in each of the attributes that is included. Table 4 presents the elasticity values that can be used to determine which attributes have more or less influence on shoppers' satisfaction. It can be seen that satisfaction is quite inelastic for all the attributes that are considered in the analysis. Nevertheless, the results for each of the attributes are not homogenous since some values are higher than others. The results show that, in general, satisfaction is more elastic for the variety of products and the choice of international brands, and it is less elastic with respect to the ease of finding specific items and the look and feel of the shops.

Table 4 Elasticities of shoppers' satisfaction (total and flight destination)

\begin{tabular}{lcccccccccc}
\hline Attribute & Total & HKG & DPS & SIN & CAN & AKL & DXB & NAN & DOH \\
\hline Variety of product items available & 0.4022 & 0.3968 & 0.4039 & 0.3892 & 0.4037 & 0.4053 & 0.4039 & 0.3968 & 0.4017 \\
Choice of international brands & 0.3919 & 0.3920 & 0.3874 & 0.3966 & 0.3904 & 0.3913 & 0.3836 & 0.3908 & 0.3941 \\
$\begin{array}{l}\text { Ease of finding a specific item you } \\
\text { were looking for }\end{array}$ & 0.3070 & 0.3231 & 0.3015 & 0.2924 & 0.3072 & 0.2888 & 0.3278 & 0.2966 & 0.2980 \\
Gifting ideas and choices & 0.3174 & 0.3140 & 0.3135 & 0.3208 & 0.3233 & 0.3120 & 0.3234 & 0.3085 & 0.3220 \\
Helpful and friendly staff & 0.3549 & 0.3591 & 0.3573 & 0.3705 & 0.3558 & 0.3470 & 0.3440 & 0.3409 & 0.3700 \\
The look and feel of the shops & 0.3091 & 0.3192 & 0.2968 & 0.3140 & 0.3329 & 0.2960 & 0.3264 & 0.2749 & 0.3220 \\
\hline
\end{tabular}


By analysing the results for each route destination, it can be noticed that the six more elastic values correspond only to one attribute (variety of product items available) in all of the routes except Singapore. Meanwhile, the six more inelastic values are observed in two attributes: ease of finding specific items (SIN, AKL, and NAN) and the look and feel of the shops (DPS, AKL, and NAN). Thus, airport managers can quickly identify that they should focus more on marketing the variety of the products and less attention should be dedicated to attributes like ease of finding a specific item and the look and feel of the shops.

\section{Discussion and conclusion}

In this study, six attributes were used to ascertain the airport duty-free shoppers' satisfaction. The results show that the place of residence and flying destination have moderating effects, so airport managers need to consider this aspect when developing strategies to enhance passengers' satisfaction. Airport managers should better promote the products that are available at duty-free shops to overseas passengers since their level of satisfaction is lower than that for Australian residents. The results obtained in this study are different from those of Lin and Chen (2013). In their research, Taiwanese travellers (i.e., national passengers) are, in general, less satisfied with the shopping experience.

Across the literature, the understanding of the satisfaction of duty-free shoppers is still scarce, and not many studies have been published on this topic. This study provides valuable insights for airport managers and academics. A better understanding of passengers' preferences regarding shopping in duty-free shops can contribute to developing commercial revenues, which represent an essential component of non-aeronautical revenues. Additionally, while other segments based on age and nationality have been more common in previous studies, one of the insights that is provided by our research is related to the importance of segmenting passengers in terms of the passengers' residence and route destination. One aspect that is not dealt with in this paper was the influence that the time of the flight could have on the duty-free shopping behaviour and satisfaction. The primary rationale was that each international destination only had one flight per day, thereby making it impossible to understand whether the shopping behaviour was influenced by this particular variable.

After analysing the ideal solutions, it was not primarily inferred that the segmentation variables played a pivotal role in explaining different levels of satisfaction since none of the components was characterised by the segmentation variables. Very short trips or other segments that are more related to the use of airport apps were the common variables that resulted in the ideal solutions. The SAT shoppers' synthetic indicator shows that Australian residents and those who travel to New Zealand are substantially more satisfied than other segments that were considered in the analysis. Additionally, non-Australian residents and those passengers travelling to Guangzhou are less satisfied than other segments.

The study offers some critical managerial insights for airport managers and other relevant stakeholders. For example, our results show that the variety of products that is available and the choice of international brands are key attributes that need to be considered by airport managers. The finding reinforces Xu and McGehee's (2012) contention that brand-conscious Chinese tourists are becoming well known for their "shopping power" and their enthusiasm for expensive high-end products. It is evident that to increase the levels of satisfaction that are experienced by airport dutyfree shoppers, a more refined study needs to be developed that takes into account the differences that are observed with respect to destination routes. 
The research uses a hybrid fuzzy-TOPSIS model to analyse airport duty-free shoppers' SAT in an Australian airport. However, the study also presents some limitations. First, due to time and resource limitations, the researchers could only design a questionnaire with just one crucial construct (satisfaction), and other vital constructs like emotions, willingness to pay or even values were omitted. Second, the survey instrument that was used in the study was originally written only in English, and so our results might be biased because of the language selection or just because the respondents did not understand the wording of the questions.

Further opportunities exist for studies that could take into account some of the previously mentioned aspects omitted in this research. For instance, future research could measure the influence of flight departure time on the behaviour and satisfaction of duty-free shopper. Other significant possibilities for future research relate to the type of airport or terminal that has been used in the study. In this sense, it is difficult to generalise the results for domestic passengers or other types of terminals, such as dedicated airline terminals or low-cost terminals that are more common in the US or the EU. New promising lines for future research can also be based on the analysis of other segmentation variables, including previous visits, the length of stay and cultural values.

\section{References}

ACI (Airport Council International). (2015). Airport Economic Report 2015. Retrieved from http://www.aci.aero/Publications/New-Releases/2015-ACI-Airport-Economics-Report

Airport Cooperative Research Program, United States. Federal Aviation Administration, LeighFisher (Firm), \& Exstare Federal Services Group, LLC. (2011). Resource Manual for Airport In-terminal Concessions (Vol. 54). Transportation Research Board.

Aydin, N. (2017). A fuzzy-based multi-dimensional and multi-period service quality evaluation outline for rail transit systems. Transport Policy, 55, 87-98.

Benitez, J. M., Martín, J. C., \& Román, C. (2007). Using fuzzy number for measuring quality of service in the hotel industry. Tourism Management, 28(2), 544-555.

Carifio, J., \& Perla, R. (2008). Resolving the 50-year debate around using and misusing Likert scales. Medical Education, 42(12), 1150-1152. doi.org/10.1111/j.13652923.2008.03172.x

Celik, E., Gumus, A.T., \& Aydin, N. (2016). An intuitionistic fuzzy approach for evaluating service quality of public transportation Systems. Uncertainty Modelling in Knowledge Engineering and Decision Making - Proceedings of the 12th International FLINS Conference, 936-942.

Chiappa, G. D., Martin, J. C., \& Roman, C. (2016). Service quality of airports' food and beverage retailers. A fuzzy approach. Journal of Air Transport Management, 53, 105-113. doi.org/10.1016/j.jairtraman.2016.02.002

Chiappa, G. D., Giménez, M. N. S., \& Zapata-Aguirre, S. (2017). Travelers Satisfaction with Food and Beverage Services in Airports. Journal of Hospitality Marketing \& Management, 26(8), 829-845. doi.org/10.1080/19368623.2017.1326866 
Chung, Y. S., Wu, C. L., \& Chiang, W. E. (2013). Air passengers' shopping motivation and information seeking behaviour. Journal of Air Transport Management, 27, 25-28.

Crawford, G. \& Melewar, T. C. (2003). The importance of impulse purchasing behaviour in the international airport environment. Journal of Consumer Behaviour, 3(1), 85-98.

Dehghani, A., Kheirkhah, A.S., \& Ahadi, H.R. (2017). A hierarchical TOPSIS method based on type-2 fuzzy sets to evaluate service quality of public transportation. International Journal of Industrial Engineering: Theory Applications and Practice, 24(5), 505-525.

Forsyth, P. (2006). Airport policy in Australia and New Zealand: privatization, light-handed regulation, and performance. Aviation Infrastructure Performance: A Study in Comparative Political Economy and Infrastructure Performance, September 2006, Madrid, Spain, 65-99.

Fowler Jr, F. J. (2013). Applied Social Research Methods: Survey Research Methods (4 ${ }^{\text {th }}$ ed.). Thousand Oaks, CA: SAGE Publications.

Freathy, P., \& O’Connell, F. (1999). Planning for profit: the commercialization of European airports. Long Range Planning, 32(6), 587-597. doi.org/10.1016/S0024-6301(99)00075-8

Geuens, M., Vantomme, D., \& Brengman, M. (2004). Developing a typology of airport shoppers. Tourism Management, 25(5), 615-622. doi.org/10.1016/j.tourman.2003.07.003

Gleave, S. D. (2017). Heathrow Airport - Review of Commercial Revenues. Retrieved from https://publicapps.caa.co.uk/docs/33/1563b_H7_Commercial_Revenues_report_by_SDG. pdf

Graham, A. (2009). How important are commercial revenues to today’s airports. Journal of Air Transport Management, 15, 106-111.

Graham, A. (2013). Managing Airports: An international perspective (4 $4^{\text {th }}$ ed.). London and New York. Routledge.

Gupta, R., Sachdeva, A., \& Bhardwaj, A. (2012). A framework for selection of logistics outsourcing partner in uncertain environment using TOPSIS. International Journal of Industrial and Systems Engineering, 12(2), 223-242.

Han, H., Hwang, J., \& Kim, Y. (2014a). Senior Travelers and Airport Shopping: Deepening Repurchase Decision-making Theory. Asia Pacific Journal of Tourism Research, 1665(February 2015), 1-28. doi.org/10.1080/10941665.2014.929156

Han, H., Kim, W., \& Hyun, S. S. (2014b). Overseas travelers' decision formation for airportshopping behavior. Journal of Travel \& Tourism Marketing. doi.org/10.1080/10548408.2014.889643

Han, H., Hwang, J., \& Kim, Y. (2015). Senior Travelers and Airport Shopping: Deepening Repurchase Decision-making Theory. Asia Pacific Journal of Tourism Research, 20(7), 761-788. doi.org/10.1080/10941665.2014.929156

Hobson, J. S. P. (2000). Tourist shopping in transit: The case of BAA plc. Journal of Vacation Marketing, 6(2), 170-183.

Hooper, P., Cain, R., \& White, S. (2000). The privatisation of Australia’s airports. Transportation Research Part E: Logistics and Transportation Review, 36(3), 181-204. 
Hu, Y. C. (2009). Fuzzy multiple-criteria decision making in the determination of critical criteria for assessing service quality of travel websites. Expert Systems with Applications, 36(3 Part 2), 6439-6445. doi.org/10.1016/j.eswa.2008.07.046

Hubregtse, M. (2016). Passenger movement and air terminal design: Artworks, wayfinding, commerce, and kinaesthesia. Interiors, 7(2-3), 155-179.

Kazemi, A., Attari, M.Y.N., \& Khorasani, M. (2016). Evaluating service quality of airports with integrating TOPSIS and VIKOR under fuzzy environment. International Journal of Services, Economics and Management, 7, 154-166.

Kistler, B., Trischler, J. \& Lohmann, G. (2018). The light-handed regulation in Australia - Is the passengers' voice represented? Transport Policy., 71, 106-115.

Kleinschmidt, T., Guo, X., Ma, W. \& Yarlagadda, P. (2011). Including airport duty-free shopping in arriving passenger simulation and the opportunities this presents. Proceedings of the 2011 Winter Simulation Conference. Brisbane, Australia: Queensland University of Technology.

Lin, W. T., \& Chen, C. Y. (2013). Shopping Satisfaction at Airport Duty-Free Stores: A CrossCultural Comparison. Journal of Hospitality Marketing and Management, 22(1), 47-66. doi.org/10.1080/19368623.2012.680242

Martín, J. C., \& Román, C. (2017). Measuring service quality in the hotel industry: The value of user generated content. Tourism, 65(4), 390-405.

Martín, J.C., Román, C., \& Gonzaga, C. (2017a). Fuzzy numbers and topsis for analyzing service quality in the MICE industry. Event Management, 21(1), 13-25.

Martín, J. C., Román, C., \& Gonzaga, C. (2017b). Quality of service and segmentation in the MICE industry: An approximation based on fuzzy logic. Journal of Convention \& Event Tourism, 18(1), 1-25.

Moulds, J., \& Lohmann, G. (2016). An analysis of future trends in non-aeronautical revenue: A case study from Adelaide Airport. Journal of Airport Management, 10(4), 343-358.

Omar, O., \& Kent, A. (2001). International airport influences on impulsive shopping: trait and normative approach. International Journal of Retail \& Distribution Management, 29(5), 226-235.

Park, J.-W., Choi, Y.-J., \& Moon, W.-C. (2013). Investigating the effects of sales promotions on customer behavioral intentions at duty-free shops: An Incheon International Airport case study. Journal of Airline and Airport Management, 3(1), 18-30. doi.org/10.3926/jairm.18

Perng, S.-W., Chow, C.-C., \& Liao, W.-C. (2010). Analysis of shopping preference and satisfaction with airport retailing products. Journal of Air Transport Management, 16(5), 279-283. doi.org/10.1016/j.jairtraman.2010.02.002

Sohn, H. \& Lee, T. J. (2017). Tourists' impulse buying behavior at duty-free shops: The moderating effects of time pressure and shopping involvement. Journal of Travel \& Tourism Marketing, 34(3), 341-356. 
Tang, Z., Qin, J., \& Sun, J. (2017). Railway emergency resource dispatching optimization based on fuzzy satisfaction degree under the priority principle. Journal of Intelligent \& Fuzzy Systems, 33(5), 2677-2686.

Tlig, H., \& Rebai, A. (2017). A TOPSIS method based on intuitionistic fuzzy values: A case study of North African airports. Management Science Letters, 7(7), 351-358.

Torres, E., Dominguez, J., Valdes, L. \& Aza, R. (2005). Passenger waiting time in an airport and expenditure carried out in the commercial area. Journal of Air Transport Management. 11, 363-367.

Xu, Y., \& McGehee, N. G. (2012). Shopping behavior of Chinese tourists visiting the United States: Letting the shoppers do the talking. Tourism Management, 33(2), 427-430. doi.org/10.1016/j.tourman.2011.05.003

Yazdani, M., Zarate, P., Coulibaly, A., \& Zavadskas, E.K. (2017). A group decision making support system in logistics and supply chain Management. Expert Systems with Applications, 88, 376-392. 
Appendix 1: Airport Survey

Q1) Do you live in Australia?

Yes (go to Q2);

No (go to Q3)

Q2) What postcode do you live in?

Four numbers: NNNN (go to Q4)

Q3) What country do you live in?

\begin{tabular}{|l|l|}
\hline Canada & Netherlands \\
\hline China (mainland) & New Zealand \\
\hline Fiji & Papua New Guinea \\
\hline France & Philippines \\
\hline Germany & Singapore \\
\hline Hong Kong & Taiwan \\
\hline India & Thailand \\
\hline Indonesia & UAE \\
\hline Italy & UK \\
\hline Japan & United States of America \\
\hline Korea, South & Vietnam \\
\hline Malaysia & Other \\
\hline
\end{tabular}

Q4) What is your flight number?

[List of flights were presented to passenger. Not disclosed here to protect the anonymity of the individual airport]

Q5) Did you use an airline lounge today?

No

Yes, Qantas Club

Yes, Singapore Airlines Lounge

Yes, Virgin Australia Lounge 
Q6) Would you use an airport common user lounge? Yes/No

Q7) What is the main purpose of your travel today?

\begin{tabular}{|l|l|}
\hline Holiday & Business, Conference \& Events \\
\hline Education & Transit \\
\hline Visiting Friends and Relatives (VFR) & Other \\
\hline
\end{tabular}

Q8) How many people (including you) are travelling together today?

\begin{tabular}{|l|l|}
\hline 1 (only me) & 4 (myself and three other people) \\
\hline 2 (myself and another person) & $5+$ (myself and at least four other people) \\
\hline 3 (myself and two other people) & Prefer not to answer \\
\hline
\end{tabular}

Q9) How many nights are you spending away from home during this trip? Three numbers: NNN Q10) How far in advance of your flight time (minutes) did you arrive at the airport today?

Less than 60 minutes (1 hour)

60-90 minutes (1 hour - 1.5 hour)

90-120 minutes (1.5 hour - 2 hours)

120-150 minutes ( 2 hours -2.5 hours)

More than 150 minutes (2.5 hours)

Q11) Did you make any purchase at the airport duty-free shopping today?

Yes (go to Q13);

No (go to Q12)

Q12) What is the main reason for not purchasing at the duty-free shopping today? (Go to Q14)

No need

The product that I am after is not available

No time

Prices are too expensive

Other

Q13) What are the reasons for shopping at the duty-free shopping today? 


\begin{tabular}{|l|l|}
\hline Cheaper price & Products not available in my own country \\
\hline Variety of goods & Indulge myself \\
\hline Guaranteed good quality & A gift to a family member/friend/colleague \\
\hline Fashion/Novelty & Lack of time elsewhere \\
\hline Unique/special products & Other \\
\hline
\end{tabular}

Q.14) What is your overall impression of the airport duty-free shopping?

\begin{tabular}{|l|l|l|l|l|l|}
\hline & $\begin{array}{c}\text { Very } \\
\text { poor }\end{array}$ & Poor & Fair & Good & $\begin{array}{c}\text { Very } \\
\text { good }\end{array}$ \\
\hline Variety of product items available & & & & & \\
\hline Choice of international brands & & & & & \\
\hline Ease of finding specific item you were looking for & & & & & \\
\hline Gifting ideas and choices & & & & & \\
\hline Helpful and friendly staff & & & & & \\
\hline The look and feel of the shops & & & & & \\
\hline
\end{tabular}

Q15) Considering your experience regarding the airport duty-free, choose the products you would like to see more?

\begin{tabular}{|l|l|l|}
\hline Australian wine & High-end fashion & Perfume/cosmetics \\
\hline Chocolates & Home appliances & Souvenirs \\
\hline Electronics & Jewellery & Tobacco \\
\hline Fitness products & Liquor/Alcohol & \\
\hline
\end{tabular}

Q16) Are you interested in buying luxury brands at the airport duty-free shopping?

Yes (include space to type what brands the pax would like to purchase)

No

Q17) Did you purchase any goods (excluding duty-free shopping) at the airport today?

Yes (go to Q18)

No (go to Question 20) 
Q18) How much did you spend on goods (excluding duty-free shopping) at the airport today (AU\$)?

Q19) What retail store did you spend the most money today?

[List of 16 airport stores was included]

Q.20) Regarding your usual shopping behaviour at airports, please rate the following statements:

\begin{tabular}{|c|c|c|c|c|c|}
\hline & $\begin{array}{l}\text { Completely } \\
\text { disagree }\end{array}$ & Disagree & Neutral & Agree & $\begin{array}{l}\text { Completely } \\
\text { agree }\end{array}$ \\
\hline I always plan my shopping at the airport & & & & & \\
\hline $\begin{array}{l}\text { I would prefer to plan my shopping online before } \\
\text { purchasing at the airport }\end{array}$ & & & & & \\
\hline $\begin{array}{l}\text { I would use a home delivery service if it was available } \\
\text { for my airport shopping }\end{array}$ & & & & & \\
\hline $\begin{array}{l}\text { If a particular shopping brand of my preference was } \\
\text { available at the airport, I would you arrive earlier to } \\
\text { shop at this store }\end{array}$ & & & & & \\
\hline
\end{tabular}

Q21) While shopping at the airport, what is your preferred method of payment?

\begin{tabular}{|l|l|l|}
\hline Cash - Australian currency & Apple Pay & Travelers check \\
\hline Cash - Foreign currency & Debit cards & WeChat Pay \\
\hline Credit cards & Prepaid travel card & Alipay \\
\hline
\end{tabular}

Q22) What brands/stores you would like to see at the Airport?

Q23) What social media platform do you usually use?

\begin{tabular}{|l|l|l|}
\hline Twitter & Instagram & Snapchat \\
\hline Facebook & WeChat & WhatsApp \\
\hline LinkedIn & & \\
\hline
\end{tabular}

Q24) If an app was developed for the airport, would you download and use it?

Yes 
No

Not sure

Q25) If an app was developed for the airport, please rank the following information regarding importance?

\begin{tabular}{|l|l|l|l|l|l|}
\hline & $\begin{array}{l}\text { Not important } \\
\text { at all }\end{array}$ & $\begin{array}{l}\text { Not } \\
\text { important }\end{array}$ & Neutral & Important & $\begin{array}{l}\text { Very } \\
\text { important }\end{array}$ \\
\hline Flight times & & & & & \\
\hline Special offers & & & & & \\
\hline Parking deals & & & & & \\
\hline Parking bookings & & & & & \\
\hline Maps & & & & & \\
\hline
\end{tabular}

Q26) How often do you travel overseas?

\begin{tabular}{|l|l|}
\hline Once every five years & $2-3$ times a year \\
\hline Once every two years & More than 4 times a year \\
\hline Once every year & \\
\hline
\end{tabular}

Q27) What is your age group?

\begin{tabular}{|l|l|l|}
\hline $15-19$ & $40-44$ & $65-69$ \\
\hline $20-24$ & $45-49$ & $70-74$ \\
\hline $25-29$ & $50-54$ & $75-79$ \\
\hline $30-34$ & $55-59$ & $80-84$ \\
\hline $35-39$ & $60-64$ & 85 and over \\
\hline Prefer not to answer & & \\
\hline
\end{tabular}

Q28) What is your gender?

Male

Female

Prefer not to declare 


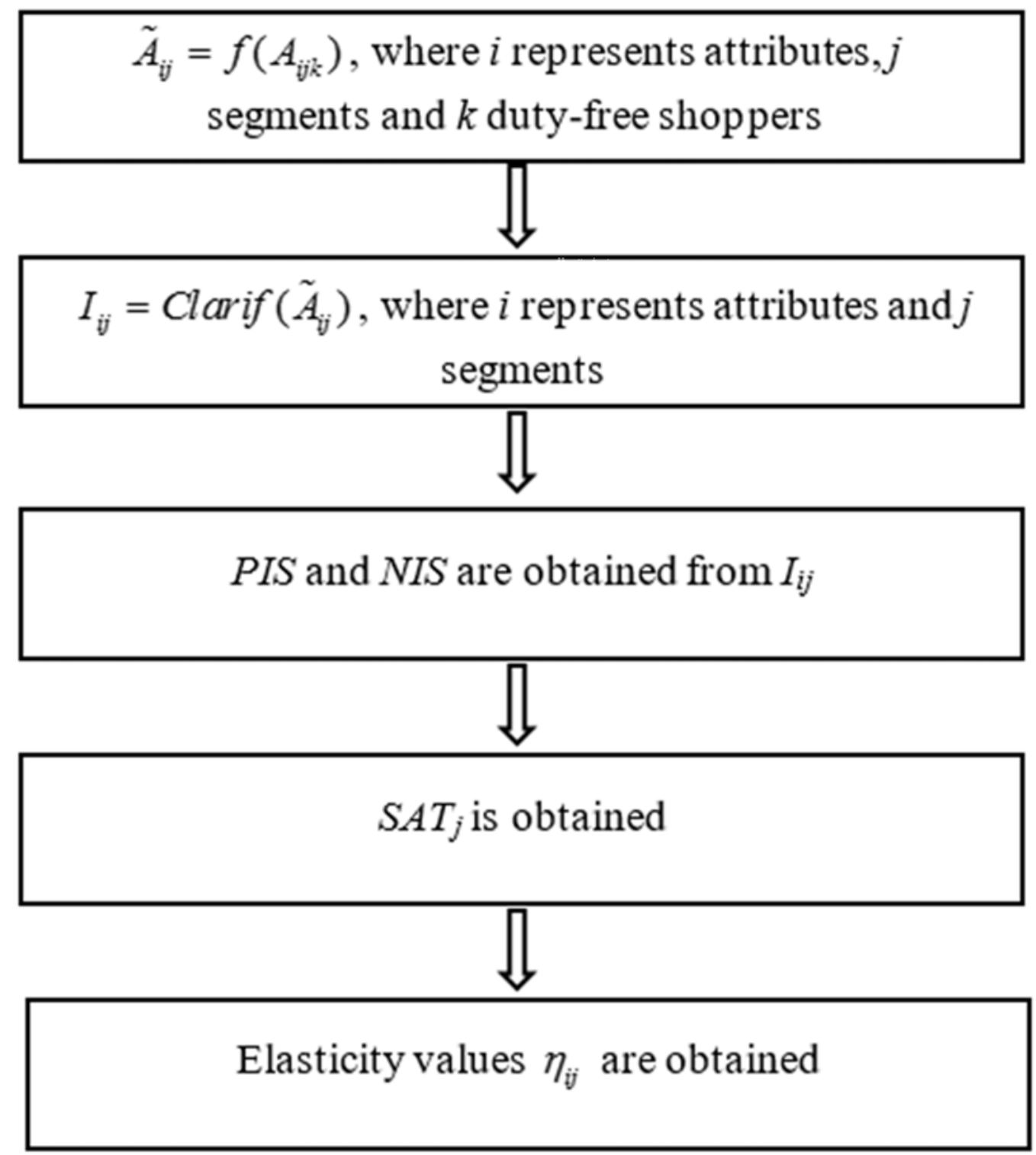




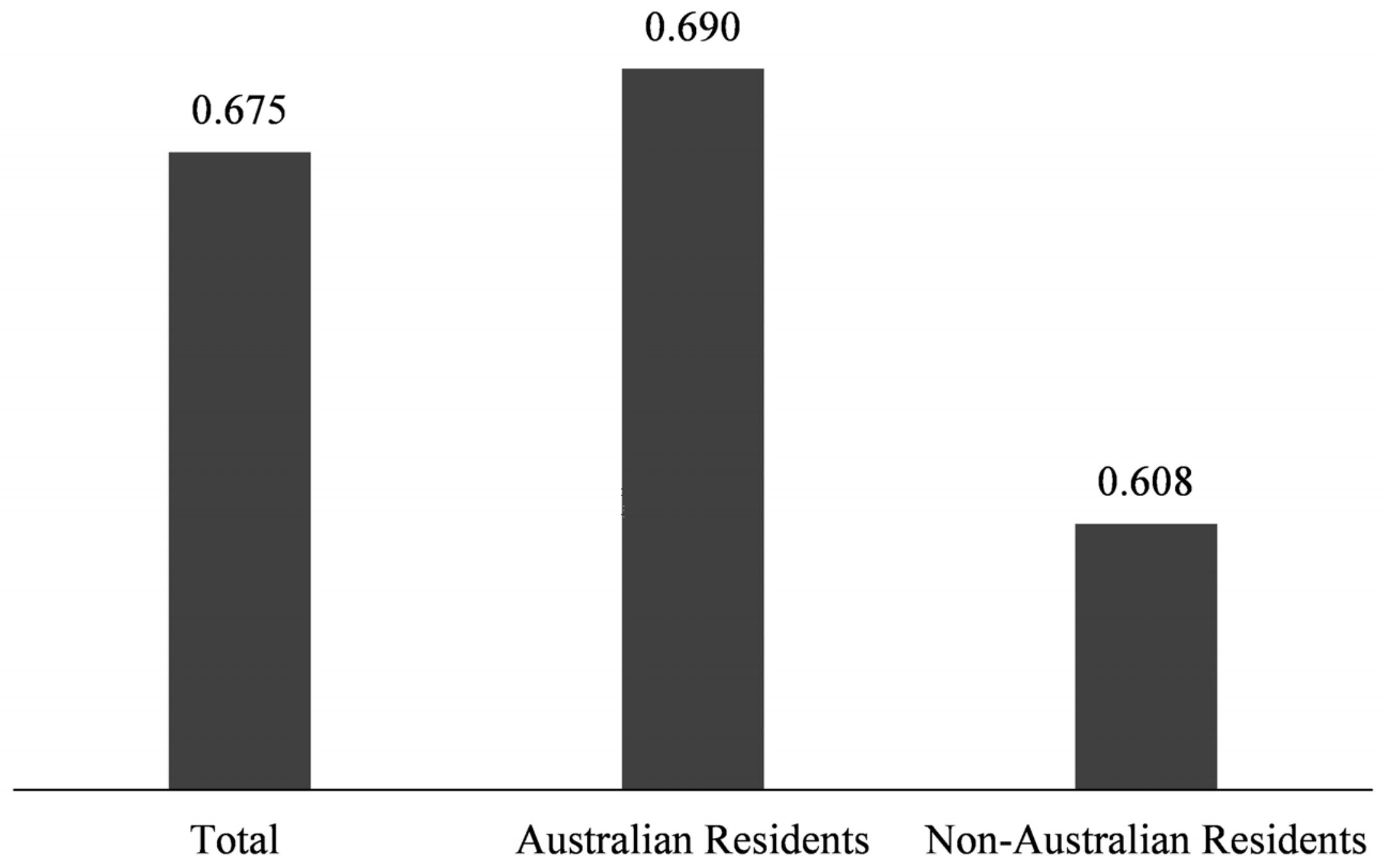




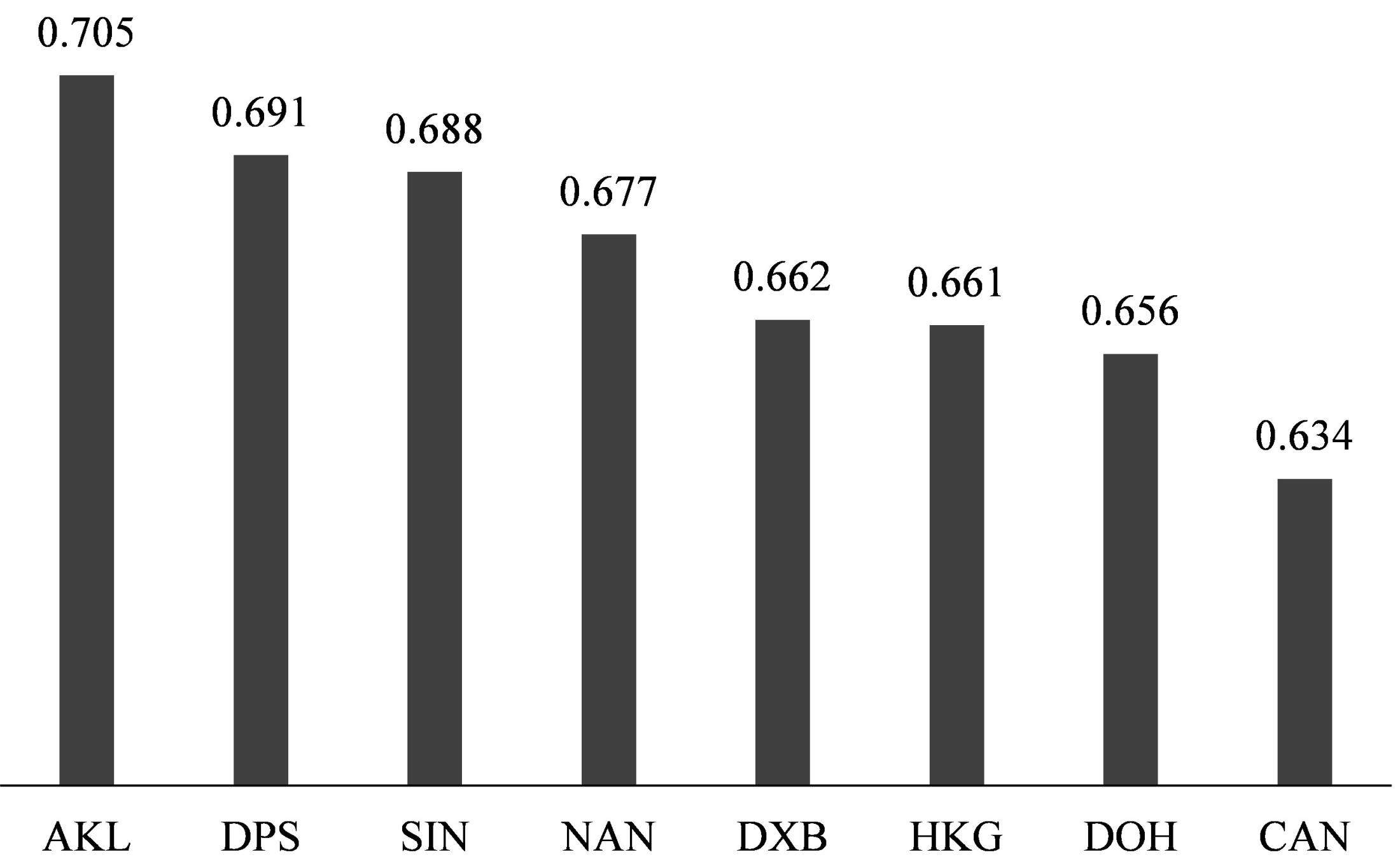

